Akingbade $\mathcal{E}$ Odebiyi, 2021

Volume 7 Issue 3, pp. 01-17

Received: 18 $8^{\text {th }}$ March 2021

Revised: 27th April 2021, 19th June 2021

Accepted: 30th October 2021

Date of Publication: 15 $5^{\text {th }}$ November 2021

DOI- https://doi.org/10.20319/pijss.2021.73.0117

This paper can be cited as: Akingbade, R. E. E Odebiyi, A. I. (2021). Women and Peacebuilding: Can Nigeria Learn from Other Countries? PEOPLE: International Journal of Social Sciences, 7(3), 01-17.

This work is licensed under the CreativeCommons Attribution-NonCommercial 4.0 International License. To view a copy of this license, visit http://creativecommons.org/licenses/by-nc/4.0/ or send a letter to Creative Commons, PO Box 1866, Mountain View, CA 94042, USA.

\title{
WOMEN AND PEACEBUILDING: CAN NIGERIA LEARN FROM OTHER COUNTRIES?
}

\author{
Retta E. Akingbade \\ Department of Psychology, Lead City University Ibadan, Nigeria \\ retta_akingbade@yahoo.com \\ Adetanwa I. Odebiyi \\ Department of Sociology, Lead City University, Ibadan, Nigeria \\ odebiyius@yahoo.com
}

\begin{abstract}
The inclusion of women in conflict resolution and peacebuilding is an important notion that has been well documented. Despite a widespread call for inclusive peacebuilding and progress in some African countries, in Nigeria, women are yet to achieve direct representation in formal peace and policy decision-making processes. The complex nature of conflict in Nigeria makes it imperative to explore all possible solutions to peacebuilding, including women's potential, which remains largely untapped. This article examined, through a review of the literature, the strategies that women employed to achieve direct representation at the table in formal peace talks in Kenya and South Africa. The conflict situations in the two countries resonate to some extent, with some of the current insurgencies in Nigeria. The strategies of both the Kenyan and South African women were similar. High-profile women in the two countries brought their skillset and competencies to work
\end{abstract}


across women's groups regardless of social, religious, or political affiliation. They formed strong coalitions and were able to unite to the lobby, dialogue, and push for representation in formal peace talks. They engaged with the government to be included as negotiators and mediators. In Nigeria, there is a need to change patriarchal norms and traditional mindsets that prevent women from representation at the peace table through sensitization. It is also essential to enlighten relevant stakeholders, especially the government, on the importance of leveraging women's skillset in peacebuilding initiatives.

\section{Keywords}

Nigeria, Women, Insecurity, Peacebuilding, Lessons

\section{Introduction}

One of the most persistent issues we contend with within Nigeria is the issue of conflictdriven insecurity - from the Boko Haram insurgency in the north; agitation for a sovereign state of Biafra and demands for secession in the south-east, to militants calling for resource control in the Niger Delta. This is besides several ethnic, religious, and social disputes in different parts of the country. More recently, there is a conflict between herders and farmers over the grazing rights of the former's cattle. Conflict is, indeed, rife in Nigeria. Among the most common causes of conflict are political, ethnic, and religious discord (Oyejide, 2020; Olaitan, 2018; NSRP, 2015).

Conflict resolution and peacebuilding are important notions of global interest. Nigeria is constantly threatened by fanatical terrorists, suicide bombings, kidnapping, insurgency, and other violent acts, claiming the lives of innocent people. It is, therefore, imperative to explore all possible solutions for responding to the situation. In Nigeria, so far, formal peacebuilding efforts, have not been extensively considered from a gendered point of view. However, patriarchal norms and traditional mindsets have not been supportive of women in leadership positions. For instance, Albert (1999) notes that men are the traditional channels of conflict resolution since they were the heads of the different units at the urban, village, neighborhood, or household level. Consequently, previous efforts at conflict resolution and peacebuilding have mostly been the purview of men, and this male bias continues to prevail, especially with regards to policy and key decision-making processes (Olaitan, 2018; Nwandinobi, 2017).

The inclusion of communities and civil society, such as representatives of churches, mosques, and ethnic organizations, as members in peace talks, only serves to perpetuate male bias 
as these are also mainly men. This is inevitable since women rarely occupy leadership roles, particularly religious ones. Potter (2008) postulates that the inclusion of women in conflict resolution and peacebuilding was superficial, questioning whether it is a "necessity" or a mere "nicety". This notion begs the question of whether any value would be added in including women in conflict resolution and peacebuilding (Marshall, 2000). These views explain, to some extent, why peacebuilding processes tend to be gender blind. However, this anomaly needs to be corrected if a strong, balanced, and sustainable peace is to be achieved. Conflict affects both men and women, albeit differently; therefore, all stakeholders must be included in striving for peace. Furthermore, excluding women in peacebuilding processes is a serious lapse in judgment, because their inclusion could help reduce conflict and advance stability (CFR, 2019). The United Nations Security Council Resolution (UNSCR) 1325 (2000) and resolution 2122 (2013) documents recommend the inclusion, representation, and participation of women in the peacebuilding process. Some countries, including Nigeria, have National Action Plans (NAP) in place to ensure that the peacebuilding process is gender-sensitive. Indeed, Nigeria's implementation of UNSCR still faces serious challenges despite a second launching of another National Action Plan for its execution (Binda, Rodriguez, Powley, Jarhum \& Gorani, 2018).

To some extent, women are now being included in formal peace processes, but their participation is still less than adequate. Research indicates that between 1992 and 2018, only 3 percent of mediators were women, 4 percent signatories, and 13 percent negotiators in major peace processes. Furthermore, only two women have served, so far, as chief negotiators (UN SC, 2019; CFR, 2019). Since women (and children) are especially vulnerable in conflict situations and suffer cruelty and displacement at the hands of combatants, it underscores the need for women to be involved in working toward peace. Indeed, it is strongly argued that wherever there is conflict, women should be part of the solution. The complex nature of peacebuilding necessitates exploring all possible solutions, including the potential role of women in peacebuilding.

Peacebuilding is an important part of the development process, and essential to the security and stability of a nation. Women may help to bring fresh insights to peacebuilding, based on their peculiar experiences, which may lead to achieving a more encompassing and sustainable peace. It is essential to adequately take into consideration, the subtle and yet persuasive roles that women can play as wives, lovers, and mothers, in lobbying for peace. Some authors are even of the view that women's contributions could not only improve the quality of the peace agreements reached, 
but also facilitate the implementation of the agreements since they have primary "responsibility for maintenance of the family and community, rebuilding peace and are the bearers of cultural and ethnic identity" (Insight on Conflict, 2017).

Also, the resultant effect, which would be evident in the breaking down of social barriers and patriarchy, would provide the opening for a more equitable society as peace and equality between women and men are related. The strategies employed by other countries could also assist Nigeria in adopting more holistic and effective ways of addressing conflict, in the light of the general global interest. This could also, in turn, influence policy and encourage mainstreaming of gender in conflict situations as well as in other spheres of life. In addition, some of the measures adopted by women in these other countries could have some theoretical and methodological relevance for Nigeria.

In this paper, Kenya and South Africa were purposively selected as cases that could be emulated because of their similarity to Nigeria; they are also ethnically diverse countries with a strongly patriarchal culture in which men are mostly the decision-makers. The conflict situations of terrorism in Kenya, and racism in South Africa, therefore, resonate, to some extent, with the current insurgencies in Nigeria.

At this juncture, it is important to define what we mean by peacebuilding in this paper. Peacebuilding in this paper is based on the definition provided by the United Nations Peacebuilding Support Office (PBSO). It defines peacebuilding as the totality of any tactic, process, and activities targeted at sustainable peace, including the prevention of further violence (PBSO, 2016). It also includes any action or approach performed with the purpose of stopping, appeasing, or settling the conflict, and promotion of social and psychological change at the grassroots, creating an environment that is conducive to sustained peace (McCarthy, 2016). This is a desk review, and the data sources are mainly secondary, including books, journal articles, Nigerian dailies, websites, and magazines.

\subsection{Objectives}

The paper highlights the role of women in peacebuilding in other countries. Women are more emotionally invested since they bear the traumatic consequences of male combatants as their significant others, and also suffer violence at the hands of the opposition. Furthermore, at the community level, as nurturers, they have a responsibility to provide safety and food. They are, therefore, likely to be more willing to seek non-confrontational approaches to peacebuilding. The 
research questions addressed in this paper include the following: Why do women continue to be excluded in formal peacebuilding efforts in Nigeria? In countries where they have been included, what was their level of involvement, and what were the outcomes? What has been the specific contribution of women to peacebuilding in other countries? Have their efforts been effective? In countries where they have succeeded, what strategies did they adopt to broker peace? Can some of these strategies or techniques be adopted by Nigerian women? These questions and many others will be addressed in this article. The specific objectives are as follows:

- Provide a brief overview of the major conflicts in Nigeria, and how they have impacted women

- Document how women have been conspicuously absent in formal peace efforts

- Describe women's role in peacebuilding in selected African countries with similar situations

- Describe the outcome of their involvement in peacebuilding in those countries

- Highlight the measures or strategies adopted by the women, which can serve as possible lessons that can be adopted in Nigeria

\section{Theoretical Framework}

The emphasis of this paper is on conflict resolution and peacebuilding, consequently, the most appropriate theory on which it can be anchored would be a consensus theory, and the most relevant one would be the functionalist theory. This is a macro-level theory emphasizing the working together of system parts to promote equilibrium and to ensure the smooth running and survival or stability of the system. The theory further suggests that gender inequalities exist within the system, which has created an efficient division of labor whereby different segments of the population are responsible for specific functions towards system survival. In this case, it means that the men have their roles towards peacebuilding, and the women have their roles too. To further explain, reference can be made to Herbert Spencer's organismic approach to society. Spencer likened society to an organism, describing how its different parts work together for the survival of the organism. In this case, therefore, the contribution of both men and women would be necessary for understanding peacebuilding. The implication of excluding women in peacebuilding is that attempts to reach sustainable peace are deficient because a significant portion of society is excluded (Haralambos \& Holborn, 2007). In Nigeria, women currently constitute 49.40 percent 
of the population (World Population Review, 2020; World Bank Report, 2019; NBS, 2017). In this wise, women, as well as men, must contribute to peacebuilding.

\section{Overview of Major Conflicts in Nigeria}

The Boko Haram and the Niger Delta crises are two of the more volatile conflicts in Nigeria that have attracted global attention. Boko Haram, a culmination of religious crises that have defined northern political engagement with the rest of Nigeria, identifies itself as a jihadist rebel group and calls for the creation of a sharia state (Alemika \& Okoye, 2002). The group came to prominence with the July 2009 uprisings in Borno State in Northern Nigeria. Since then, the insurgency has led to the loss of thousands of lives, massive displacement, and a significant impact on economic activities (Oyejide, 2020). Boko Haram continues to wage violent war in its bid to create an Islamic state and wipe out Western influence from schools (Sahara Reporters, 2017; Cosmo, 2015; BBC, 2014).

The Niger Delta militants, on the other hand, are agitating for local control of the crude oil, which is almost the solitary Nigerian foreign exchange earner. Fallouts of the crises in the Niger Delta include recurrent acts of violence, pipeline vandalism, oil bunkering, and a full-blown crisis that affected global oil prices and forced the government to declare amnesty for militants in the region; the crisis has cost Nigeria billions of dollars in foreign exchange (Eboh, 2018).

Asides from these ideology-driven conflicts, there is the escalation of communal clashes between Fulani herdsmen and farmers in agrarian communities across the country. These clashes worsened in 2018, resulting in the death of at least 1,600 people and displacing some 3,000 people in northern Nigeria (Nigeria World Report, 2019). The clashes are purportedly backlashed against encroachment on traditional grazing lands of herders and have cumulatively cost Nigeria billions of dollars in assets and investment opportunities as well as millions of lives.

\section{Impact of Conflict on Women}

The crises across the country adversely impacted women and girls, threatening their lives and security. For instance, the Boko Haram conflict led to the abduction of some 276 schoolgirls. These girls' education was terminated, and they were forced to accept Islam, among other atrocities. Some suffered physical and sexual violence resulting in unwanted pregnancies. Some other studies have shown that women and girls, as a result of the sexual violence they experienced, 
contracted various sexually transmitted diseases, including HIV and AIDS (Stewart, 2010; McKay \& Mazurana, 2007). Thus, women's social, economic, and reproductive lives were impacted by conflict. The marginalization of women in peacebuilding processes prevents them from proffering gender-sensitive policy decisions (CEDAW, 2017; Sahara Reporters, 2017).

Following from the above, conventional wisdom would dictate that women are likely to be more emotionally invested in conflict resolution and peacebuilding since they not only suffer violence at the hands of the opposition but also bear the traumatic consequences of male combatants that are their significant others. Indeed, being so adversely affected, they would be highly motivated to be a part of finding sustainable solutions as vicarious casualties of conflict.

\section{Women's Role in Peacebuilding}

There is a growing recognition of the important role that women can play in the prevention and resolution of conflict and peacebuilding. As the world grapples with issues of global security and its attendant humanitarian implications, all the major actors to the conflict must be factored into peacebuilding efforts. Unfortunately, conflict resolution and peacebuilding are areas in which, according to McKay (1996), the biases disfavor women, are strong and largely unnoticed. Postconflict graphic images further work to perpetuate perceptions of gender roles. Men are usually portrayed in strong roles, as combatants, usually in battle fatigue or bearing the scars of war. Women, on the other hand, are portrayed as weak and passive casualties of war or as widowed victims, thus serving to reinforce cultural stereotypes of women's status. Indeed, statistics show that 97 percent of women and children are the predominant casualties of modern warfare, bearing a lot of the physical and psychological scars of battle (Stewart, 2010; McKay \& Mazurana, 2007; Levy \& Sidel, 1997; U.N., 1996).

All conflicts, intra- or international, protracted or short-lived, eventually come to an end. The likelihood of resumption of hostilities is largely dependent on the ability of the parties involved to agree upon the terms of reconciliation, and commitment to the peacebuilding process. Fortna's (2008) examination of 94 cease-fires in almost 60 civil wars in the post-Cold War period until 1999, found that war resumes within a year in one in three cases, and within five years in half of the cases. The seeming unsustainability of peace and reconciliation processes reinforces the exploration of as many alternative routes and participants to the peacekeeping process, with the 
gendering of the peacekeeping and peacebuilding process being a major option (Adjei, 2019; McCarthy, 2011).

McCarthy (2011), in her examination of the roles of women in peacebuilding efforts in four African civil wars, thought that the inclusion of women in peacebuilding is an effective step toward increasing the probability of a successful peace outcome. Indeed, women's participation in the peace process is said to contribute to the durability of the peace, making it 64 percent less likely to fail, and 35 percent more likely to last at least 15 years (International Peace Institute, 2015; Nilson, 2012). Indeed, Binda, et al (2018) reiterates that including women in the peace process can increase the chances of peace agreements lasting more than two years by 20 percent, and at least 15 years by 35 percent.

Gbowee (2015) supports the notion that it was the absence of women on the peace table in South Sudan that led to the failure of peace talks in that country. Conflict in Sudan lasted over 30 years, with women bearing the brunt of the conflict. Gbowee (2015) further opined that there can be no successful resolution of conflict without the full participation of women. She is of the thought that women are the ones who can make a significant difference to the quality of the negotiations. She further opined that peace talks are 64 percent less likely to fail if women are included as illustrated by the case of the Philippines, where the role of women in peace negotiations led to the end of a 45-year civil war (Beever, 2010). According to Gbowee (2018), women could change the narrative by ignoring ethnic, religious, and political differences, and coming together to negotiate for peace.

Gbowee (2018) also affirmed that for peace to be sustained in Liberia, women had to participate in political decision-making as this had implications for their social, economic, and reproductive lives. They impressed on women that peace was not just the absence of conflict but also active involvement in choosing who governed them. Thus, in Liberia, the Mano River Union Women Peace Network (MARWOPNET), Association of Female Lawyers, the Gbowee Peace Foundation, and other women's groups contributed immensely to the build-up of the peace process and eventual rehabilitation process, which was deemed to be effective (Gbowee, 2018; UNDP, 2011).

Mckay (1996) affirms that considering conflict resolution and peacebuilding from a gender lens would provide more comprehensive information on what has been done if we are to know 
how to proceed to achieve desired outcomes. In other words, it is necessary to look back to move forward.

\subsection{Women and Peacebuilding in Nigeria}

In Nigeria, the participation of women in formal peacebuilding processes has been minimal, although, women have, to some extent, tried to influence peacebuilding through advocacy. In northern Nigeria, for example, groups, such as the Women Peace and Security Network in Borno State, the Angwan Rogo Peace Network, and Women Without Walls Initiative in Plateau State, have protested the violence that led to the loss of lives, especially of women and children, and for the safety of their partners, who are at a disadvantage in the face of the firepower of the insurgents (UNWomen, 2017; Nwadinobi, 2017). The women of the peace networks worked across groups, uniting Muslim and Christian women, to agitate for peace in their communities (UNWomen, 2017).

The government's response to peacebuilding has not favored women, because it has mostly been gendering biased. Most panels of inquiry have been skewed towards men, and women have been visibly absent, except for a few cases. One of such was the one chaired by Justice Rahila Hadea Cudjoe, following the Kaduna State riots in 1992, and the Judicial Commission of inquiry, in which Dr. Eleanor Nwadinobi participated, to investigate the death of worshippers at the Government Technical College in Enugu State, in 2002. There was also a token female participant in one of the panels of inquiry, which was set up to look into the Jos crises in 2004 (Olaitan, 2018, NRSP, 2013).

Historically, women have been involved in pushing for peace. Previously in Nigeria, involvement in peacebuilding was evident in the activities of women, such as Funmilayo Ransom Kuti, and Margaret Ekpo, who were the early activists of women's rights in Nigeria. These women were renowned for campaigning for the active participation of women in politics, and the protection of their rights. Hajia Gambo Sawaba pioneered women's rights advocacy in northern Nigeria. Some other notable women were Queen Amina of Zaria, a "warrior queen”, who ruled for some 34 years and expanded her territory considerably by conquering several states. The Queen Mother of the Benin monarchy was critical to political decision-making, and Nwanyewura led the Aba Women's Riots to resist the imposition of tax on women in southeast Nigeria (God'spresence, 2014). Women walked naked, chanting and weeping, usually as a last resort to force the government to act, when faced with desperate situations that affected their security (NRSP, 2013). 


\subsection{Women and Peacebuilding in Kenya}

Kenya, like Nigeria, is a multi-ethnic country; conflict is endemic, with a high level of insecurity. Just like Nigeria, conflict in Kenya has been attributed majorly to inter-communal clashes, election violence, competition over limited resources, and terrorist attacks, among other issues. Conflict in Kenya is persistent, and it is reported to still be on the increase (Rohwerder, 2015). Electoral disputes were a major cause of the conflict that led to the death of more than 1,000 people during protests over the 2007 presidential elections. Other causes of conflict in Kenya are attributed to political discrimination, long-standing land disputes, ethno-religious crises, pervasive poverty, and unemployment, among others (CFR, 2019).

Women's groups contributed significantly to the peace process, the ending of violence, and the holding of peaceful presidential elections in Kenya. The resolution of the conflict that arose from the presidential elections in 2007, involved a significant number of women in high profile positions, such as senior advisors to mediators, support staff to senior political officials and committees as well as leaders of civil society. The Kenyan Women's Consultative Group (KWCG), a collection of Kenyan women from diverse backgrounds, significantly influenced the peace talks of 2008-2013. Indeed, 25 percent of the negotiating team were women, and 33 percent were mediators (Inclusive Peace and Transition Initiative, IPTI, 2016).

An important part of the strategies used by the women included venting sessions, where a collection of Kenyan women from different ethnic groups and political affiliations met to share their different ideologies, to arrive at a compromise. The venting sessions led to a unified women's group that greatly influenced the peace agreement. Kenyan women drew on their skillsets and expertise to mobilize civil society women at every level - urban and rural, and especially at the grassroots level. They further lobbied, utilized mediation and dialogue, and held meetings to rub minds and exchange ideas. They formed strong local, national, and international networks, and were among the first to engage with the UN to lobby for peace (Sugh \& Ikwuba, 2017). A considerable number of civil society and community-based organizations were part of the process. The women also worked with religious and political leaders.

Kenyan women certainly approached peace talks in a very systematic manner; first, by addressing barriers through the holding of the venting sessions, then discussing and presenting their proposals to a larger group, and upon reaching an agreement, would present them at the peace talks. The proposals were usually developed by a team of women experts. The women shared 
information, supported, and drew strength from each other, and met regularly to discuss with different groups. They started with an initial group of 24 women leaders, which gradually increased to 50 women leaders from different sectors, including lobbyists, negotiators and mediators, civil society, politicians, and religious and ethnic groups. Caucuses and workshops were also used to engage people. The groups of women combining skills resulted in a formidable force to influence the peace process (Sugh \& Ikwuba, 2017).

\subsection{Women and Peacebuilding in South Africa}

South Africa is also similar to Nigeria, because of its multi-ethnic groups comprising Africans, Indians, Dutch, and other racial groups. South Africa has undergone a prolonged history of brutal violence and inter-racial conflict. The country suffered from a prolonged lack of peace and stability, with deep-rooted and complex insecurity and instability, especially during the Apartheid regime (Irobi, 2005). Women were instrumental to peacebuilding in South Africa, especially with regards to its democratic transition from the period 1990 to 1998 . Their influence, to a large extent, led to a non-racist and gender-sensitive constitution and the first democratic elections. Strategies adopted by women to effectively influence the peace process included highlevel consultations with non-governmental organizations (NGOs), women leaders, gender experts, and constitutional lawyers, to push for greater inclusion in peacebuilding and gender equality. Specifically, the Women's Coalition used negotiations and mobilized mass action to advocate for the greater inclusion of women in the peacebuilding process.

Like Kenya, women in South Africa were able to successfully form strong cross-sectional alliances and influence the inclusion of gender equality into the constitution as well as ensuring a gender quota for female candidates in the first democratic elections in 1994 (IPTI, 2018). Feminist activists challenged the Truth and Reconciliation Commission (TRC) and argued for the establishment of a Gender Equality Truth and Reconciliation Commission. They insisted that the gendered nature of truth must be addressed. The TRCs in South Africa successfully included women, and they were well represented; more than half of the women who testified at three separate hearings focused exclusively on women. As a result, there have been improvements in subsequent TRCs because of the limitations of the first South African TRC (Meintjes, 2012; Kusafuka, 2009). 


\section{Lessons for Women in Nigeria}

The preceding literature shows that the strategies of both the Kenyan and South African women were similar. High-profile women in the two countries brought their skillset and competencies to work across women's groups regardless of social, religious, or political affiliation. They formed strong coalitions and were able to unite to the lobby, dialogue, negotiate and push for representation in formal peace talks.

In addition to the strategies utilized by Kenya and South Africa, a plethora of strategies were also utilized by women in other African countries, such as Liberia, Ghana, Sierra Leone, Rwanda, and Guinea. Coalitions were an especially effective strategy too in all these countries. In Liberia for instance, the Mano River Women's Peace Network was useful in bringing to the table, the heads of state of Liberia, Sierra Leone, and Guinea to negotiate peace. The Network conducted peace workshops, calling for the inclusion of women in peacebuilding, educating women on how they can participate in the process, mobilizing women from all walks of life, and collaborating with other peace groups. Women's police stations were established to address gender-specific issues without fear of discrimination. Other non-violent strategies were the use of street theatre or edutainment to sensitize and educate people, peace walks, peace talks, vigils, and peaceful demonstrations (Mazurana and Mckay 1999).

It has been suggested that solutions to the conflict should be "homegrown" (Matu \& Mckay, 2014). According to these authors, effective peacebuilding starts with women at the grassroots, and that women at the grassroots should pursue solutions that would work for them rather than those foisted on them by outsiders. Following this, employing grassroots NGOs and faith-based organizations is a good foot-in-the-door that could effectively contribute to peacebuilding. These organizations can be leveraged to adopt the strategies discussed to push for peace in their communities.

For example, the DFID-sponsored Nigeria Stability and Reconciliation Programme (NRSP), and the UN Women-supported peace and security networks are good starting points in Nigeria. The Bring Back Our Girls campaign over the abduction of 276 schoolgirls in April 2014, is an example of peaceful protests that informed some response from the government. The persistent protest marches by mostly women's groups requesting the government to negotiate with the captors, the Islamist terrorist group, Boko Haram, to secure the release of the girls, eventually 
led to the freeing of 83 of them in 2017 (The Guardian, 2017; Sahara Reporters, 2017; Ogundipe, 2016; Cosmo, 2015; BBC, 2014).

The countries discussed are also patriarchal societies like Nigeria; thus, if they could create the space with some success, albeit, limited then women in Nigeria should also be able to do the same. There are, however, bound to be some challenges with such cultural practices as keeping women in Purdah, for example, to expect some women to participate in street walks, protests, etc. Nevertheless, these women should be able to map out their line of action, and not wait for the men to include them in peace committees. Binda, et al, (2018) reiterates the need to change perceptions of women as passive victims if inclusivity is to be achieved. They further state that the perception that women do not have the required skill set to take a seat at the peace table should be changed. To this end, they advocate training and multimedia campaigns to educate all citizens, excombatants, leaders of civil society, government, and minority groups, on the importance of including women in peacebuilding initiatives. Beyond advocacy women, should be trained in mediation, peace negotiations, and other peacekeeping activities. It has been suggested that a "critical mass" of at least 30 to 35 percent of women, should be involved in peace negotiations, and indeed, in all peacekeeping activities, for an impact to be felt (Nwadinobi, 2017; CEDAW, 2017; CFR, 2003).

\section{Conclusion}

Having outlined the strategies used elsewhere, we cannot conclude without mentioning the peculiarities of the Nigerian situation. Insecurity is an important issue that Nigerians contend with, and which is inimical to development. Although there has been some limited success with Boko Haram and militancy in the Niger Delta, it is remarkable that despite the still widespread spate of conflict, government silence is loud in its lack of definitive strategies to resolve the conflicts. Indeed, according to one of the highest-ranking military officers of the Nigerian Army, conflict in Nigeria seems to defy all solutions. He states that military intervention alone cannot combat terrorism and other threats to national security, and even advocates the need for spiritual intervention, because of the ideological nature of the war (Unini, 2019). A spiritual dimension to national security had also been previously noted (Pogoson, 2013).

From the preceding literature, several non-threatening, non-violent strategies were used by women to protest conflict and to build peace. Women used diverse methods, formal and informal 
to participate in peacebuilding. In the countries discussed, women's coalitions and alliances played a very crucial role. This was attributed to their ability to mobilize, organize and lobby. The literature has thus, demonstrated that women have influenced peacebuilding significantly (Gbowee, 2018; Beever, 2010; McCarthy, 2011; Stewart, 2010). It is evident that women have gone beyond being passive victims to active participants in the peace process. Furthermore, their involvement is more likely to result in more sustainable peace.

The question, however, is how do we then situate effective conflict resolution in the light of the government's admission of its inability to cope? We recognize that conflict resolution is not as simplistic as merely modeling strategies from elsewhere. Since women have been excluded in formal peacebuilding, and in the face of lack of political will by government, and recognition of their inability to solve the problem of insecurity, perhaps it is, indeed, time to seriously consider what insight women can bring to the table. In this wise, women should be given the opportunity to acquire skills in negotiation, mediation, and other peacekeeping activities. Future research may want to explore knowledge levels and attitudes of different categories of women in Nigeria towards the inclusion, representation, and participation of women in formal peacebuilding processes.

\section{REFERENCES}

Albert, I.O. (1999). Ife-Modakeke Crisis. In O. Otite, I.O, Albert (Eds.), Community Conflicts in Nigeria: Management, Resolution, and Transformation. Ibadan: Spectrum Books Ltd. Alemika, E., and Okoye F. (Eds.). (2002). Ethno-Religious Conflicts and Democracy in Nigeria: Challenges. Kaduna, Human Rights Monitor.

Anderlini, S.N. (2007). Women Building Peace: What They Do, Why It Matters. Boulder, CO. Lynne Rienner Publishers.

BBC News (2014, April 30). Nigeria girls'abduction: Protest March in Abuja. bbc.com/news/world-africa-2721693

Binda, F., Rodrigues, C., Powley, E., Jarhum, R., and Amel, G. (2018, December 3). Women in peacebuilding: Tactical Dialogue. https://doi.org/10.1007/978-3-319-97949-6_2

CEDAW Committee (2017). Women, Peace, and Security in Nigeria. Joint Shadow Report.

Cosmo (2015, June 9). Bring back our girls. Cosmo reports. https://www.cosmo.ph/tag/bringbackourgirls. 
Council on Foreign Relations, CFR (2003, March 6). The Role of Women in Peacebuilding and Reconstruction: Lessons from Rwanda, East Timor, and Afghanistan.

Council on Foreign Research, CFR (2019, January 30). Women's participation in peace processes. https://www.cfr.org/interactive/womens-participation-in-peace-processes.

Fortna, V.P. (2008). Does Peacekeeping Work? Shaping Belligerents' Choices After Civil War. Princeton. Princeton University Press. https://doi.org/10.1515/9781400837731

Franzoi, S.L. (2000). Social psychology (2 ${ }^{\text {nd }}$ ed.). The United States. McGraw- Hill.

Haralambos, M. and Holborn, M. (2008). Sociology: Themes \& Perspectives. ( $7^{\text {th }}$ ed.). London. Harpers and Collins.

Inclusive Peace \& Transition Initiative, IPTI (2017). Case Study Series: Women in Peace and Transition Processes. Guatemala. https://www.inclusivepeace.org/sites/default/files/IPTI_case-studies-women-Guatamala1994-1999.pdf" https://www.inclusivepeace.org/sites/default/files/IPTI_case-studieswomen-Guatamala-1994-1999.pdf.

Inclusive Peace \& Transition Initiative-IPTI (2017). Case Study Series Women in Peace and Transition Processes. https://www.inclusivepeace.org/sites/default/files/IPTI_casestudies-women-Guatamala-1994-1999.pdf" https://www.inclusivepeace.org/sites/default/files/IPTI_case-studies-women-Guatamala1994-1999.pdf.

International Crisis Group (2016, December 1). Nigeria: Women and the Boko Haram Insurgence. Africa Report No 242, 5 December 2016. https://www.crisisgroup.org/africa/west-africa/nigeria/nigeria-women-and-boko-haraminsurgency

Irobi, E.M. (2005). Ethnic Conflict Management in Africa: A Comparative Case Study of Nigeria and South Africa. http://www.beyond" http://www.beyond intractability.org/casestudy/irobi-ethnic

Isis-WICCE (November. 2008). A situation analysis of the women survivors of the 1989-2003armed conflict in Liberia. Kampala: Isis-WICCE.

Johnson, S.A. (2017). The Mano River Women's Peace Network (2001). https://www.blackpast.org/global-african-history/mano-river-women-s-peace-network$\underline{2001 /}$ 
Kusafuka, A. (2009). Truth Commissions and Gender: A South African Case Study. https://doi.org/10.4314/ajcr.v9i2.52172

Marshall R. (2000). Women in War and Peace: Grassroots Peacebuilding. Washington, United States Institute of Peace. Peaceworks No.34. https://www.usip.org/publications/2008/08//women-war-and-peace-grassrootspeacebuilding

McKay, S. (1996). Gendering Peace Psychology. Peace and Conflict: Journal of Peace Psychology, 2, 93-107. https://doi.org/10.1207/s15327949pac0202_1

Meintjes, S. (2012). South Africa's Truth and Reconciliation Commission and Gender Justice. Heinreich BollStiffling Gunder Internet Institute of Feminism and Gender Democracy. gwi-boell.de/en

Nigeria Stability and Reconciliation Programme, NSRP (2017). Impact Report: Output 3, Women and Girls in Peacebuilding and Conflict Management. http://www.nsrpnigeria.org/wp-content/uploads/2017/12/Impact-Report-Women-and-Girls.pdf

Nigeria Stability and Reconciliation Programme, NSRP (2015). Nigeria Watch Project: Fifth Report on Violence in Nigeria. Nigeria, The French Institute for Research - IFRA.

Nigeria Stability and Reconciliation Programme, NSRP (2013). The Role of Women and Girls in Peace Initiatives in Nigeria. nsrp-nigeria.org/wp-content/uploads/2013/WomenPeace-and-Security-Study.pdf. 17 August 2020

Nigeria World Report (2019). Nigeria Human Rights Watch (2018). http://www.hrw.org/world report/2019/country-chapters

Nwadinobi E.A. (2017). Role of Women in Peace Initiatives. Intel Prop. Rights. 5: 195. DOI: 10.4172/2375-4516.1000195. Accessed August 11, 2020. https://doi.org/10.4172/2375$\underline{4516.1000195}$

Olaitan, Z.M. (2018, 11 October). Women's participation in peace processes in Nigeria: Challenges and Prospects. https://www.researchgate.net/publications/328216329 August $11,2020$.

Oyejide, T.A. (2020). Ethnic Diversity, Conflicts, Political Structure and Socio-Economic Inequality in Nigeria. Guest Lecture, Faculty of Environment, Management and Social Sciences, Lead City University, Ibadan. 5 March. 
Peace Direct (2017). Insight on Conflict: Peacebuilding and Gender. https//: www.insightonconflict.org/themes/gender-women-peacebuilding-and-gender

Pogoson, A. I. (2013). Nigeria's National Security in an Age of Terrorism. Maiden Departmental Lecture, Department of Political Science. University of Ibadan, 17 April.

Potter, A. (2008). Gender Sensitivity: Nicety or Necessity in Peace-process Management? Centre for Humanitarian Dialogue. http://www.ethz.ch/isn/90800/Gender_Sensitivity_06_08.pdf

Rohwerder, B. (2015). Conflict Analysis of Kenya. Birmingham, U.K. GSDRC. The University of Birmingham. gdrcwww.org/wp-contentuploads/2015/KenyanConflict.pdf

Sahara Reporters (2017, June 1). Kidnapped Chibok Girls Freed. Retrieved from www.saharareporters.com/2017/05/06//80-kidnapped-chibok-girls-freed-boko-haram

Sugh, E.T. and Ikwuba, A. (2017, July 31). Women in Mediation and Conflict Resolution: Lessons, Challenges and Prospects for Africa. IOSR Journal of Humanities and Social Sciences (IOSR-JHSS), 22, (1) 1-6. Retrieved from www.iosrjournals.org https://doi.org/10.9790/0837-2201020106

UNDP (2011). Human Development Index: 2010 Rankings.

Unini, C. (2019, September 30) https://thenigerialawyer.com/spiritual-efforts-needed-to-defeatboko-haram-burutai/Posted

United States Institute of Peace (2012). An Explanation of the Landmark Resolution on Women, Peace, and Security. usip.org/gender_peacebuilding_about_UNSCR_1325UN

UNSC (2019, October 9). Women and Peace and Security. Report of the Secretary-General http://www.undocs.org/en/S/2019/800

UN Women (2012). Facts and Figures: Women, Peace, and Security. Retrieved from http://www.unwomen.com

Yafugborhi, E. (2016, February 23). Militants threaten blow-up of more oil installations. Vanguard Nigeria. www.vanguardngr.com/2016/102/militants-threaten-blow-up-of$\underline{\text { more-oil-installations }}$ 